Survey

\title{
Helping "light green" consumers walk the talk: Results of a behavioural intervention survey in the Swiss electricity market
}

\author{
Dorian Litvine ${ }^{\mathrm{a}, *}$, Rolf Wüstenhagen ${ }^{\mathrm{b}, 1}$ \\ a University of Montpellier 1, LASER-CREDEN, UFR d'Economie, Rue Raymond Dugrand, CS 79606, 34960 Montpellier Cedex 2, France

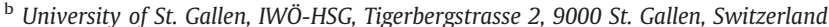

\section{A R T I C L E I N F O}

\section{Article history:}

Received 18 August 2009

Received in revised form 7 September 2010

Accepted 8 October 2010

Available online 3 December 2010

\section{Keywords:}

Green power marketing

Theory of planned behaviour

Field experiment

Willingness-to-pay

\begin{abstract}
A B S T R A C T
While many consumer surveys show very positive attitudes towards renewable energy, the share of consumers actually purchasing green electricity is still in the single-digit percent range in most countries. What can be done to help consumers with positive attitudes towards green electricity to "walk the talk", i.e. to behave consistently with their preferences? We developed a psychological model based on the theory of planned behaviour (TPB) to design a large-scale behavioural intervention survey with 1163 Swiss electricity consumers. Our results show that by providing information targeted at the key factors influencing the intention to purchase green electricity, namely attitudes towards purchase, social norms and perceived behavioural control, a significant increase in green electricity market share can be achieved. Our results show that price is not the only barrier to purchasing green electricity, and that information to increase the perceived benefit of buying green electricity as well as targeted communication to overcome inertia among retail electricity consumers are equally important factors.
\end{abstract}

(C) 2010 Elsevier B.V. All rights reserved.

\section{Introduction}

More than six million residential and business customers worldwide buy green electricity (REN21, 2010). In so doing, they may contribute to the development of new renewable energy capacity. However, there is still a gap between positive attitudes towards renewable energy, which typically is in the $80 \%$ range in many countries, and actual purchasing behaviour for green electricity, which is often in the single-digit percent range. The price premium for green electricity is often referred to as a key factor in explaining the gap between attitude and behaviour (Borchers et al., 2007; Farhar, 1999; Kotchen and Moore, 2007; Menges et al., 2005; Roe et al., 2001). While this seems intuitively plausible from an economic point of view, there is some puzzling counter-evidence. For example, marketers in the Netherlands and some other countries offer green electricity products where the price premium is minimal, zero or even negative, and yet customer demand remains relatively modest (Bird et al., 2002, pp. 524-525).

\footnotetext{
* Corresponding author. Tel.: +33689151574.

E-mail addresses: dorian.litvine@univ-montp1.fr (D. Litvine), rolf.wuestenhagen@unisg.ch (R. Wüstenhagen).

URLs: http://www.creden.univ-montp1.fr/fr/litvine.html (D. Litvine), http://goodenergies.iwoe.unisg.ch (R. Wüstenhagen).

1 Tel.: +41712242587.
}

The purpose of the paper is to shed more light on the nuanced relationship between price and demand for green electricity by answering the following research questions:

1. What is the influence of perceived benefit on explaining consumer decisions to purchase green electricity, and what are the key components of this benefit?

2. What is the relative role of price in explaining barriers to purchasing green electricity?

3. How can green electricity marketers or policy makers increase the perceived benefits of purchasing green electricity?

These research questions will be answered by drawing on the results of a field experiment among 1163 electricity customers in the city of St. Gallen (Switzerland), which was designed based on the Theory of Planned Behaviour (Ajzen, 1988, 1991).

The structure of the paper is as follows. Section 2 reviews relevant literature on green electricity marketing and the influence of information on environmental behaviour, and concludes with a causal model linking consumer attitudes and behaviour. Section 3 presents the methodology of the empirical survey. Section 4 presents and discusses main results, section $\mathbf{5}$ highlights some limitations of this study that can provide starting points for further research, and section 6 concludes the paper with implications for green electricity marketing and renewable energy policy. 


\section{Literature Review}

\subsection{Green Electricity and the Private Provision of Public Goods}

Green electricity can be considered a privately provided good with public benefits (Clark et al., 2003; Kotchen, 2006; Kotchen and Moore, 2007; Menges et al., 2005). These benefits, or positive externalities, include, for example, avoided emissions of conventional power generation, contribution to job creation in the renewable energy industry, and reduction of resource import dependence. However, green electricity is not a purely public good, since its purchase involves a private cost. Market diffusion of green electricity is characterized by a social dilemma (Palfrey and Rosenthal, 1988), which weakens the link between attitudes and behaviour, and consumers' willingness to voluntarily contribute to the public good (Andreoni, 1988; Bergstrom et al., 1986), resulting in strategic behaviour such as free riding or waiting for others before taking own action.

While the private cost of purchasing green electricity is obvious, the private benefits of this behaviour are less clear. In contrast to the purchase of other environmental products, such as organic food, the positive implications of buying green electricity are rather intangible (Byrnes et al., 1999; Markard and Truffer, 2006; Wüstenhagen, 2000). Rather than direct health benefits as in the case of organic food, the private benefits of purchasing green electricity can for example be a positive contribution to achieving societal goals like the development of future energy technologies or an increasing share of renewable energy. However, it is conceptually challenging to link personal behaviour to these outcomes since they may be remote in space and time. Capturing such private benefits of a collective good might then be a significant motivation to contribute (e.g. effect on local employment, landscape and health improvement, contribution to energy price stability, etc.). A more direct personal benefit might be to reduce one's personal carbon footprint or respect other personal values. Another set of benefits is tied to social interaction effects. The act of purchasing green electricity may provide the consumer with a feeling of being part of a network of peers, and hence be reinforced by bandwagon effects (Wiser, 2007) or increasing returns (Arthur, 1989).

While conventional economic analysis would suggest that customers only buy goods for their private benefits, the theory of privately provided public goods (Bergstrom et al., 1986; Andreoni, 1988) can help explain the empirical evidence that people do indeed buy green electricity by pointing to different types of altruism (cf. Litvine, 2008). Pure altruism refers to a behaviour that is only driven by the desire to increase the public good in order to enhance collective well-being. At the other end of the spectrum, pure egoists showing no altruism will only buy when there is private benefit for them and their peers. In our survey, we consider such benefits through tangible (local) outcomes of development of renewable energies. Between these two extremes, impure altruism is defined in our survey as a motivation where the individual derives private satisfaction only from contributing to the public good (warm-glow of giving), and from the contribution of others (social interactions; cf. Andreoni, 1990; Menges et al., 2005; Rose et al., 2002; Brekke et al., 2003; Ek and Söderholm, 2008). Arguably, impure altruism is empirically more widespread than either pure altruism or pure egoism, and it has been demonstrated to be a significant predictor for pro-environmental intentions (De Groot and Steg, 2010).

The aspect of private versus public benefits and forms of altruism can be linked to the diffusion of green electricity among different customer segments. Wüstenhagen (2000) distinguishes dark green, light green and other customers. Dark green customers are early adopters of eco-products, buying early on for the pure sake of the public benefit. At the other end of the spectrum, customers who do not care about the environment will not be reached until they perceive green electricity to have a higher private benefit than conventional electricity. Between those two extremes, there is a large segment of light green customers that can also be referred to as the target group "beyond the eco-niche" (Wüstenhagen, 2000). Those light green customers buy green electricity partly for its private benefits, but partly also for varying degrees of impure altruism. Consequently, we consider the perceived personal benefit of buying green electricity to be a combination of the different forms of altruism. ${ }^{2}$

Many studies have investigated the willingness to pay (WTP) for green electricity in various countries (Borchers et al., 2007; Byrnes et al., 1999; Farhar, 1999; Hansla et al., 2007; Roe et al., 2001; Rose et al., 2002; Wiser, 2007). Between $40 \%$ and $70 \%$ of European households state a positive willingness to pay extra for green electricity, and between $27 \%$ and $50 \%$ say they would accept a $5 \%$ premium on their bill (Eurobarometer, 2005; Palmer, 2003). While it is hard to describe a clear socio-demographic profile of the typical green electricity customer, factors that have been to shown to be positively correlated with WTP in previous studies are membership in environmental organizations, having children, a liberal political orientation, and knowledge about energy issues. Clark et al. (2003), Hansla et al. (2007), Kotchen and Moore (2007), Poe et al. (2002), and Rose et al. (2002) point to strategic and psychological determinants of WTP for green electricity and actual purchase, including altruistic motivations, environmental awareness and self-transcendence values, and Wiser's (2007) contingent valuation survey points to social and normative influences on the purchasing decision.

An important contribution of our survey is to go beyond previous studies in two ways: 1) We consider a more comprehensive set of underlying factors that determine customer preferences for green electricity (see Appendix 1), and categorize them in a conceptual model based on the Theory of Planned Behaviour (TPB), 2) we investigate how these motivational factors are linked to behaviour in a real-life context by designing and conducting a large-scale field experiment.

\subsection{From Attitudes to Action: The Theory of Planned Behaviour}

The Theory of Planned Behaviour (Ajzen, 1988, 1991) is a widely used model in social psychology. It provides a useful framework for a deeper analysis of factors determining purchase decisions related to green electricity. While the Theory of Planned Behaviour (TPB) has been widely used to explain environmental behaviour (Kaiser and Gutscher, 2003; Kaiser et al., 2005; Kalafatis et al., 1999; Oreg and Katz-Gerro, 2006; Ozcaglar-Toulouse et al., 2006; Sparks and Shepherd, 1992; Bamberg and Schmidt, 1998; Fishbein, 1995; Fishbein and Ajzen, 2005, 2010; Heath and Gifford, 2002), only few studies have used elements of this approach to investigate attitudes and behaviour related to renewable energy and green electricity (Bang et al., 2000; Peters and Feldman, 2001). One of the main advantages of TPB for analysing environmental action is its ability to consider a large set of complex determinants in a relatively simple framework. Behaviour is explained through just three main variables: attitude toward behaviour $\left(A_{B}\right)$, subjective norms $(S N)$ and Perceived Behavioural Control (PBC). While this reduction of complexity is useful, the predictive power of the TPB model has often been improved by extensions to the three main variables.

In designing our survey, we selected three additional concepts (Fishbein, 1995) which proved to be accurate determinants of environmental behaviour in previous research:

\section{- personal norms refer to feelings of moral obligation to act pro- environmentally (Ek and Söderholm, 2008; Harland et al., 1999; Heath and Gifford, 2002; Kaiser et al., 1999; Kotchen and Moore, 2007; Parker et al., 1995; Steg et al., in press),}

\footnotetext{
${ }^{2}$ This hypothesis is supported through the concept of "multiple motives" and its importance for explaining pro-environmental behaviours (cf. Lindenberg and Steg, 2007; Steg et al., in press).
} 


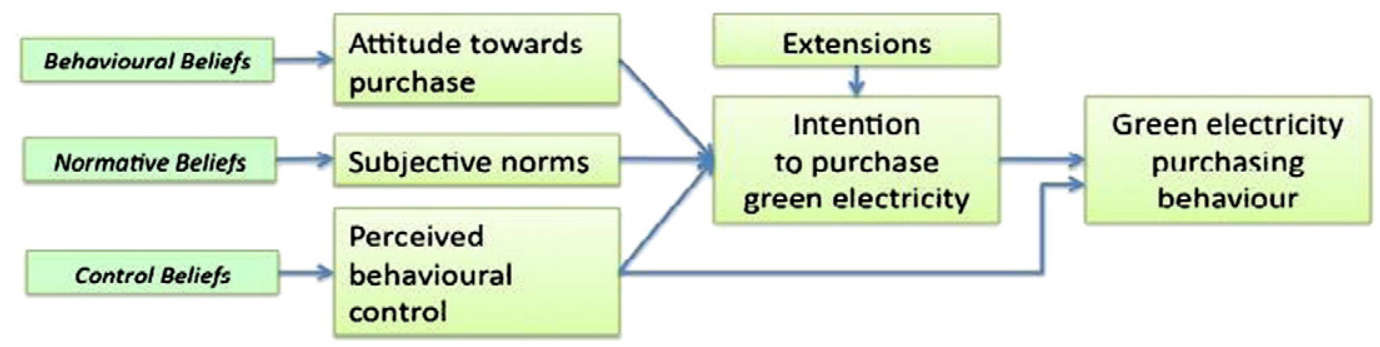

Fig. 1. Conceptual model - explaining green electricity purchases with TPB approach.

- perceived self-efficacy (PSE) refers to the individual's perception that his/her effort is efficient and useful to attain a desired goal (Bandura, 1977, 1997). PSE is widely acknowledged as a central action factor in explaining pro-environmental behaviour (Bamberg and Möser, 2007; Fishbein, 1995; Kaiser and Gutscher, 2003; Pieters et al., 1998).

- expected guilt refers to a feeling of moral regret that an individual will experience if not behaving pro-environmentally (Ajzen and Fishbein, 2005; Heath and Gifford, 2002; Kaiser, 2006; Kaiser et al., 1999; Manstead, 2000).

At the essence of TPB is a two-stage action model, which we apply to the case of green electricity purchasing behaviour in Fig. 1. In the first stage, three categories of beliefs concerning the purchase of green electricity can be characterized: the expected consequences of buying green electricity (behavioural beliefs); how the customer expects important referents to approve (or disapprove) his purchases of green electricity as well as the action level of others (normative beliefs); how easy or difficult he perceives the act of purchasing green electricity and the presence of factors that may further or hinder performance of this behaviour (control beliefs). The three main variables used to explain a given behaviour $\left(A_{B}, S N\right.$ and $\left.P B C\right)$ are formed from the aggregation of these beliefs. Together the three predictive variables (and extensions) set the level of behavioural intention. ${ }^{3}$ In the second stage of the model, this behavioural intention, together with a direct influence from perceived behavioural control (PBC) in a given situation, determines actual purchasing behaviour.

The TPB is based on a subjective expected utility logic, which does not explicitly recognize that individual behaviour may also be rooted in altruistic values. However, the three categories of beliefs considered in the TPB may be linked to the forms of altruism we outlined above. The beliefs concerning the consequences of green electricity on others (pure altruism), or on oneself and one's peers (egoism) are considered through the variable $A_{B}$ (attitude towards behaviour). The beliefs concerning inter-personal links (impure altruism) may be considered through SN (moral, injunctive and descriptive norms). And finally, PBC's extension to include Perceived Self Efficacy allows us considering the moral component of impure altruism (Goeree et al., 2002; Hausman and McPherson, 1996). The variable PBC can also take into account information asymmetries (distrust in the market, impression of ignorance, signal offered by the others' choice, etc.) and rational aspects linked to the perception of control (time, income, inability to operate the purchase, etc.).

\subsection{Using Information to Promote Pro-Environmental Behaviours}

Providing information is one of the main strategies used in intervention studies or field experiments explaining how to promote pro-environmental behaviours (Bator and Cialdini, 2000; Bamberg and Schmidt, 1998; Cialdini, 2003; Hopper and Nielsen, 1991; Schultz,

\footnotetext{
${ }^{3}$ The TPB model assumes that the three variables are independent of each other, however interaction effects are also conceivable.
}

1998; Verplanken and Wood, 2006; cf. also Fishbein, 1995, Jackson, 2005; Stern, 1999). Information may be provided through various channels, such as workshops, discussion groups, mass media, tailored information, experimental tasks, etc. A set of key variables is generally targeted by interventions, as it accounts for most of the variation in a wide range of behaviours (Fishbein, 1995): intentions, skills, environmental constraints, norms, self-standards, emotional reactions, and self-efficacy. In their review of studies aimed at changing energy conservation behaviour, Abrahamse et al. (2005) point out that several interventions also focus on increasing households' awareness of environmental problems, behavioural consequences, and personal responsibility. According to Schwartz's norm-activation model, this kind of information is supposed to influence personal norms, a process at the heart of several studies (cf. Lindenberg and Steg, 2007; Stern, 1999). Public information activating altruistic values and moral norms can indeed encourage behaviour at an individual or community level, even if the targeted action is running contrary to pure private incentives and there is a risk of free riding. Nyborg et al. (2006) develop a theoretical model that predicts that policy makers or marketers can potentially achieve major changes in consumer behaviour through advertising that changes consumers' impression of the green alternative's market share. Reiss and White (2008) stress how public appeals and information about costs of a collective action failure have encouraged most of households to reduce their energy consumption during the Californian energy crisis in 2000/2001 ("I want to do my part"), and Jacobsen (2010) shows how following the release of Al Gore's documentary An Inconvenient Truth, residential purchases of voluntary carbon offsets increased by $50 \%$.

One of the challenges of intervention studies focused on using information to influence pro-environmental behaviour is that the resulting changes in behaviour may be short-lived, especially when the impact of an action appears to be small, or strong habits are present. While this problem can partly be overcome by providing incentives and/or clarifying benefits (Stern, 1999), creating lasting impacts requires consideration of a broader set of determinants for action, and notably satisfying different motivations and expected outcomes from contributing to green electricity. However, among the thirty-eight surveys examined by Abrahamse et al. (2005) and numerous other interventions surveyed, only very few adopt a comprehensive approach targeting different categories of beliefs and action factors that could be able to change the individual's perceived benefit, intention and behaviour. Our study intends to overcome these shortcomings of pure information campaigns by taking a more comprehensive approach, based on the Theory of Planned Behaviour. The TPB model allows to take into account the causal chain from beliefs to action, where information can indeed create new salient beliefs or make existing beliefs more prominent in a particular situation, hence strengthening behavioural intentions and consequently increasing likelihood of pro-environmental action. In comparison to previous field experiments taking a TPB approach (Ajzen, 2002c; Bamberg and Schmidt, 1998; Fishbein, 1995; Fishbein and Ajzen, 2005, 2010; Heath and Gifford, 2002), a unique aspect of 
our experimental design is that we address each of the belief categories separately by providing targeted information to each of the five experimental groups.

\section{Methods, Data, and Sample}

The data presented here are based on a survey among residential electricity customers in the city of St. Gallen (Switzerland) conducted between September 2006 and January 2007. At the time of the survey, the municipal utility, Sankt Galler Stadtwerke, had been offering green electricity products for five years: Aquapower, a product based on $100 \%$ hydropower, priced at a premium of about $10 \%$, and Solar Power, a pure PV product mostly supplied from local plants, priced at a premium of about $400 \%$. The total number of subscribers for these two products had remained in the low single-digit percent range. As the Swiss electricity market is not liberalized yet, no competitors have conducted aggressive marketing campaigns for (green) electricity, so existing customers had mainly been acquired through occasional bill inserts, and overall awareness of the existing product offerings was relatively low outside a core of environmentally aware customers.

After a pre-survey by phone, the invitation to participate, with URL and login, was sent out as a paper bill insert to more than 31,000 private electricity customers of the municipal utility. 1380 customers participated in the online survey, of which 1192 respondents completed the full questionnaire (response rate: 4.3\%). After some data cleaning, a final sample of 1163 respondents was used in the analysis. The final sample consisted of 1007 (86.5\%) respondents who were not currently buying green electricity, and 156 (13.5\%) who were already green electricity customers.

The online questionnaire of the main survey consisted of four main parts. After an introduction page explaining that the University of St. Gallen was surveying inhabitants' views on energy and environmental issues in order to develop a public information campaign and to improve the provision of electricity services in their region, part 1 of the questionnaire asked for general personal preferences on energy and environmental issues. In part 2 , the sample was divided into six groups, one control group and five experimental groups that were exposed to information targeted at specific belief categories of the TPB model presented in Fig. $1{ }^{4}$ The information provided to groups $G_{A B 1}$ and $G_{A B 2}$ was targeting the variable attitude towards purchase, with the first group highlighting social benefits and the second group highlighting the private benefits of purchasing green electricity. Group $G_{S N}$ was exposed to information targeting subjective norms. Group $\mathrm{G}_{\mathrm{PBC}}$ received information influencing perceived behavioural control, and finally group $G_{\text {Mixed }}$ was exposed to a mix of the information provided to the other four experimental groups. Examples for the information provided to each of the groups are described in Table 2. Part 3 of the questionnaire was the same for all groups again, and measured the independent variables of the model as well as the intention to purchase green electricity. Finally, part 4 of the questionnaire asked for a number of socio-demographic variables.

Four months after the main survey, we conducted a short follow-up survey with a subset of the sample by phone $(\mathrm{N}=22)$ and internet $(\mathrm{N}=331)$, asking for news and events that may have influenced their intention to purchase green electricity. In parallel, we registered all the

\footnotetext{
${ }^{4}$ Based on the cognitive methodology and persuasion literatures, we involved respondents in the processing of information, increasing personal relevance and treatment impact (cf. Bator and Cialdini, 2000; Jackson, 2005; Krosnick, 1999; Pratkanis and Greenwald, 1993; Petty et al., 1983; Sudman et al., 1996). We notably asked each respondent on a 5-points Likert scale how useful the specific items of information would be to help the consumer's decision between conventional and green electricity, and whether it should hence be part of a public information campaign on green electricity.
}

Table 1

Characteristics of sample versus reference person of average Swiss household.

\begin{tabular}{llll}
\hline & & $\begin{array}{l}\text { Sample } \\
(\mathrm{N}=1163)\end{array}$ & $\begin{array}{l}\text { Switzerland average } \\
(\mathrm{BFS} 2005,2007)(\%)\end{array}$ \\
\hline \multirow{2}{*}{ Sex } & Male & 65.6 & 63.2 \\
\multirow{2}{*}{ Age } & Female & 34.4 & 36.2 \\
& 18-24 years & 8.0 & 3.6 \\
& 25-54 years & 65.6 & 59.0 \\
Monthly Income & more than 55 years & 26.4 & 37.4 \\
(household) $^{\mathrm{a}}$ & less than 3000 CHF & 13.6 & 13.9 \\
& 3001-6000 CHF & 38.9 & 27.1 \\
\multirow{2}{*}{$\begin{array}{c}\text { Electricity } \\
\text { choice }\end{array}$} & 6001-10,000 CHF & 33.4 & 40.6 \\
& more than 10,000 CHF & 14.2 & 17.4 \\
& green electricity & 13.5 & 4 \\
& default electricity & 86.5 & 96
\end{tabular}

a Source: Bundesamt für Statistik [BFS] (2007), Assumption: 1.45 working people per household.

b Source for Swiss average: own estimates based on various sources.

new subscriptions to green electricity in the city of St. Gallen and determined whether they occurred from participants of the survey or customers outside our sample. 25 of the 331 participants of the internet version of the follow-up survey were new subscribers, and 17 of them indicated that participating in the main survey had a positive influence on their decision to become a green electricity customer, while most of these new subscribers said other events and information in four-month period after the survey had not consciously influenced their decision to purchase.

Table 1 provides a summary of the characteristics of the 1163 respondents participating in the main survey. Overall, the sample provides reasonable representativeness compared to the average Swiss household with a few exceptions. Young adults ( $<24$ years) are somewhat overrepresented (8.0\% vs. 3.6\% among all Swiss households) in our sample, while people older than 55 years are somewhat underrepresented $(26.4 \%$ vs. $37.4 \%$ ), which may be a result of the fact that the survey was conducted online. Similarly, the average income in our sample is slightly below Swiss average, with the strongest deviation in the second to highest income class (33.4\% vs. $40.6 \%$ ). As for gender, the sample almost perfectly matches the distribution of the household reference persons as defined by the Swiss official statistics (BFS 2005), however, compared to the general population, men are clearly over-represented. One reason is that the invitation to participate was sent out to the standard bill recipient of the municipal utility of St. Gallen, and the default for those recipients in multiperson households is the man. The most significant deviation from the overall population is that green electricity customers are over-represented by about a factor of 3 in our sample, as might be expected in a survey on this topic through some degree of self-selection bias. Since our aim was not primarily representativeness, but rather to understand the motivation and action of those customers who had positive intentions, but not subscribed yet, we excluded the 156 existing green electricity customers from the overall sample for the analysis presented in this article Table 2.

\section{Results}

We report the findings from our empirical survey in three parts. First, we present the results on determinants of intention and action within the standard TPB model and an extended model. Indeed, as pointed out by Fishbein (1995), the factors explaining intention and action should be the main determinants of behavioural change. Second, we compare changes in behaviour between the experimental groups and the control group. Third, we discuss the role of perceived benefit in moderating the relationship between price and decision to purchase.

\subsection{Determinants of Intention and Action}

Table 3 shows the results of two models: Model 1 represents the standard TPB model as introduced in Fig. 1, where Model 1a assesses 
Table 2

Description of four experimental groups [note: a fifth experimental group was treated with a mix of the information provided to the other four groups ( $G_{\text {mixed }}$ ); the control group did not receive any information].

\begin{tabular}{|c|c|c|c|c|}
\hline Experimental Group & $\mathrm{G}_{\mathrm{AB} 1}$ & $\mathrm{G}_{\mathrm{AB} 2}$ & $\mathrm{G}_{\mathrm{SN}}$ & $\underline{\mathrm{G}_{\mathrm{PBC}}}$ \\
\hline Targeted TPB variable & Attitude toward behaviour & Attitude toward behaviour & Subjective norms & Perceived behavioural control \\
\hline $\begin{array}{l}\text { Belief family } \\
\text { (variable components) }\end{array}$ & $\begin{array}{l}\text { Behavioural beliefs }(1-\text { social benefits): Is it } \\
\text { likely that purchasing green electricity will } \\
\text { lead to positive outcomes? Does green } \\
\text { electricity purchase have a real impact on } \\
\text { social benefits (health, environment, future } \\
\text { generations, etc.)? }\end{array}$ & $\begin{array}{l}\text { Behavioural beliefs ( } 2-\text { private benefits): Is } \\
\text { it likely that purchasing green electricity will } \\
\text { lead to positive outcomes? Does green } \\
\text { electricity purchase have a real impact on } \\
\text { private benefits ("now, here, for me and my } \\
\text { peers")? }\end{array}$ & $\begin{array}{l}\text { Normative beliefs: Does purchasing green } \\
\text { electricity enable me to conform with } \\
\text { expectations of my reference group } \\
\text { (injunctive), and to fulfill some moral } \\
\text { obligations (personal)? Are enough people } \\
\text { purchasing green electricity to make it a } \\
\text { norm (descriptive)? }\end{array}$ & $\begin{array}{l}\text { Control beliefs: Is purchasing green } \\
\text { electricity easy to do and can I overcome the } \\
\text { obstacles I am expecting (perceived } \\
\text { simplicity)? Can I make a beneficial choice } \\
\text { and then act (skills, information, and } \\
\text { resources such as time or money) (internal } \\
\text { and external control)? Will my contribution } \\
\text { help reach general expected outcomes such } \\
\text { as an increased share of renewable more } \\
\text { quickly (perceived self-efficacy)? }\end{array}$ \\
\hline Type of altruism & $\begin{array}{l}\text { Pure altruism: concerned with the global } \\
\text { level of contribution, interested in the } \\
\text { positive outcomes of green electricity for } \\
\text { others, society, and future generations. }\end{array}$ & $\begin{array}{l}\text { Egoism: concerned with the visible and } \\
\text { tangible outcomes of purchasing green } \\
\text { electricity (direct benefits on the private } \\
\text { sphere) }\end{array}$ & $\begin{array}{l}\text { Impure altruism: private satisfaction derived } \\
\text { from the individual contribution itself, } \\
\text { without asking for results. Interested in the } \\
\text { social interaction created by green electricity } \\
\text { purchase. }\end{array}$ & $\begin{array}{l}\text { Impure altruism: private satisfaction derived } \\
\text { from the individual contribution itself, with } \\
\text { some concern about the concrete efficiency } \\
\text { of his/her own contribution. Interested in the } \\
\text { social interaction created by green electricity } \\
\text { purchase. }\end{array}$ \\
\hline $\begin{array}{l}\text { Examples of information } \\
\text { provided to participants }\end{array}$ & $\begin{array}{l}\text { - Efficiency of paying a premium: Each } \mathrm{kWh} \\
\text { purchased }=1 \text { polluting } \mathrm{kWh} \text { avoided; } \\
\text { impact on stimulating growth of renewable } \\
\text { energy; } \\
\text { - To reinforce the customers' confidence } \\
\text { in... 1) the use of the premium (current use, } \\
\text { new capacities and technology } \\
\text { development); } 2 \text { ) the justification of } \\
\text { premium levels based on production cost; } 3 \text { ) }\end{array}$ & $\begin{array}{l}\frac{\text { Same information as for } \mathrm{G}_{\mathrm{AB} 1} \text {, but reducing it }}{\text { to the household level in terms of time and }} \\
\text { space. } \\
\text { Other information: } \\
\text { - Emphasizing the local proximity of the } \\
\text { renewable energy projects (pictures, etc.) } \\
\text { - Emphasizing the co-benefits of green } \\
\text { electricity on personal health, energy price } \\
\text { stability, energy self-sufficiency, and }\end{array}$ & $\begin{array}{l}\text { - Actual green electricity purchase rates for } \\
\text { Switzerland and St. Gallen; } \\
\text { - A large part of Swiss households are } \\
\text { willing to act more environmentally friendly } \\
\text { if they observe that others do the same (poll } \\
\text { results); } \\
\text { - How many Swiss households favor } \\
\text { development of renewable energies (poll } \\
\text { results); }\end{array}$ & $\begin{array}{l}\text { - Emphasizing the level of reliability and } \\
\text { control over the process, from the } \\
\text { household's purchase to the production of } \\
\text { "green electrons"; } \\
\text { - Ease of purchase (convenience, multiple } \\
\text { product options, simple process, etc.); } \\
\text { - Possibility to return to conventional } \\
\text { electricity supply without obstacles } \\
\text { (individual control of the decision); }\end{array}$ \\
\hline & $\begin{array}{l}\text { the credibility of the certification institution; } \\
\text { - Stability of the renewable energy projects, } \\
\text { actual and future growth in production; } \\
\text { - Pollution avoidance: equivalence of total } \\
\text { purchases in terms of avoided radioactive } \\
\text { waste, greenhouse gasses and global } \\
\text { pollution. }\end{array}$ & $\begin{array}{l}\text { employment levels (on national and regional } \\
\text { levels). }\end{array}$ & $\begin{array}{l}\text { - Purchasing green electricity as taking part } \\
\text { in a progressive citizen movement } \\
\text { (leadering); } \\
\text { - Prominent citizens buy green electricity } \\
\text { (imitation); } \\
\text { - Planned publication of a list of all green } \\
\text { electricity customers in the city will show } \\
\text { who is acting and make others aware of own } \\
\text { contribution. }\end{array}$ & $\begin{array}{l}\text { - Possibility to request more information } \\
\text { about green electricity at any time; all } \\
\text { households in the city have equal access to } \\
\text { information; presentation of organizations } \\
\text { providing free information about green } \\
\text { electricity and renewables; } \\
\text { - Purchasing green electricity is a pro- } \\
\text { environmental action requiring a small } \\
\text { effort; in the absence of political support } \\
\text { schemes, growth of renewable energy in } \\
\text { Switzerland depends on household } \\
\text { contributions; purchasing decision leads to } \\
\text { decreasing prices through scale effects. }\end{array}$ \\
\hline
\end{tabular}


Table 3

Factors determining intention to purchase and actual behaviour.

\begin{tabular}{|c|c|c|c|c|c|}
\hline \multirow[t]{2}{*}{ INTENTION $^{\mathrm{a}}$} & \multirow{2}{*}{$\frac{\text { Model 1a }(\mathrm{N}=170)}{\text { Coeff. } \beta \text { (t value) }}$} & \multirow{2}{*}{$\frac{\text { Model 2a(N=170) }}{\text { Coeff. B (Std. Err.) }}$} & \multirow[t]{2}{*}{ ACTION $^{\mathrm{b}}$} & \multirow{2}{*}{$\frac{\text { Model } 1 \mathrm{~b}(\mathrm{~N}=1007)}{\text { Coeff. } \beta \text { (t value })}$} & \multirow{2}{*}{$\begin{array}{l}\text { Model 2b }(\mathrm{N}=1007) \\
\text { Coeff. B (Std. Err.) }\end{array}$} \\
\hline & & & & & \\
\hline$A_{B}$ & $0.52^{\dagger}(7.68)$ & $0.21^{\text {*** }}(2.75)$ & Intention & $0.52^{\dagger}(0.07)$ & $0.27^{\text {*** }}(0.08)$ \\
\hline $\mathrm{PBC}$ & $0.22^{\dagger}(3.42)$ & - & $\mathrm{PBC}$ & $0.25^{\dagger}(0.11)$ & - \\
\hline SN & $-0.02(-0.25)$ & - & & & \\
\hline Perceived simplicity & - & $0.14^{* *}(2.21)$ & Personal norms & - & $0.32^{* *}(0.15)$ \\
\hline \multirow[t]{2}{*}{ Benefit certainty } & - & $0.45^{\dagger}(5.65)$ & Perceived Self-efficacy & - & $0.11^{* *}(0.08)$ \\
\hline & & & General WTP & - & $0.58^{\dagger}(0.15)$ \\
\hline Adj. $R^{2}\left(\Delta R^{2}\right)$ & 0.319 & $0.437(+0.118)$ & Nagelkerke R² (c) & 0.191 & $0.287(+0.089)$ \\
\hline F stat. (df) & $27.39^{\dagger}(3 ; 166)$ & $32.41^{\dagger}(4 ; 158)$ & $\chi^{2}$ stat. (df) [adding stat] & $424.4(2)^{\dagger}[-78.71]$ & $379.3(5)^{\dagger}[-17.75]$ \\
\hline
\end{tabular}

** $\mathrm{p}<0.05 ; * * * \mathrm{p}<0.01 ; \dagger \mathrm{p}<0.001$

a Data on intention was taken from the control group only in order to avoid bias from the information treatment.

b Data on action was taken from all groups except those who had already purchased green electricity at the time of the survey, due to the small number of new green electricity subscriptions in the control group.

c As R $\mathrm{R}^{2}$ statistics cannot be exactly computed for logistic models, an approximation is evaluated.

the variables that influence the intention to buy green electricity, ${ }^{5}$ whereas Model 1b looks at actual purchasing behaviour. Model 2 represents a different approach, where additional variables ${ }^{6}$ were taken into account, namely perceived simplicity ${ }^{7}$ and benefit certainty as factors influencing intention (Model 2a), and personal norms, perceived self-efficacy and general willingness-to-pay ${ }^{8}$ as factors influencing behaviour (Model 2b). For behavioural intention, the analyses were conducted with the control group only in order to increase external validity and reduce potential bias through the information treatment in the experimental groups. However, due to the small number of purchases in the control group, we included all other groups in the models assessing actual behaviour.

Model 1a presents the results of the regression of intention within the basic TPB model. The final linear model $^{9}$ predicts intention accurately $[\mathrm{F}(3 ; 166)=27.39 ; \mathrm{p}<0.001]$ and the three TPB variables together explain $32 \%$ of the intention variance. Compared to other studies of environmental behaviour, this is a reasonable value. With the exception of Kaiser and Gutscher's (2003) survey aggregating various pro-environmental actions, which had significantly higher explanatory power $\left(R^{2}=81 \%\right)$, TPB studies usually explain between 20 and $40 \%$ of the variance (e.g. Harland et al., 1999; Ozcaglar-Toulouse et al., 2006; Sparks and Shepherd, 1992). All other things being equal, customers' intention to purchase green electricity increases with a positive attitude toward purchase ${ }^{10}(\beta=0.52 ; \mathrm{p}<0.001)$ and Perceived Behavioural Control $(\beta=0.22 ; p<0.001)$. In other words, intention increases when the consumer thinks the purchase generates outcomes they value positively, and when they feel they can purchase green electricity easily and the action is under their control.

An interesting finding is the low and insignificant value for the influence of Social Norms on the intention to buy green electricity in

\footnotetext{
${ }^{5}$ To increase the validity of our intention measure, we used a "cheap talk" presentation: "We frequently overestimate our intention to undertake ecological behaviours. Considering that, do you intend to purchase green electricity in the forthcoming months?"

${ }^{6}$ See Appendix 1 for a detailed description of the additional variables.

7 We use "perceived simplicity" rather than the term "perceived difficulty" which is common in the environmental behaviour literature, so that an increasing scale-score means a positive impact on intention.

${ }^{8}$ We used a 7-points Likert scale to assess the general willingness to pay a premium ("Is it conceivable for you to pay more for green electricity?" from "no, not at all" to "yes, absolutely").

${ }^{9}$ Linear treatment of polynomial data is possible because scales complying with the TPB framework are considered as interval data; see Ajzen, 2002a; Tabachnick and Fidell, 2006, p.6 and 7.

${ }^{10}$ Items of the Osgood scale have been chosen based on our pilot survey. We chose four items with higher Cronbach's alpha (0.8): good/bad, harmful/beneficial, worthless/valuable, and crucial/secondary.
}

our study. SN is the only variable not significant to explain intention $(\beta=-0.017 ; p>0.1)$ in the basic TPB model. This result, which is quite frequent in the TPB literature (Ajzen and Fishbein, 2005), is rare when explaining pro-environmental behaviours. The low influence of social norms may be a result of a lack of critical mass in the local green electricity market of St. Gallen. Due to the small number of green electricity customers, visibility of this behaviour was low, also because marketing and communication efforts of the local utility were limited at the time of the survey, so normative pressure had not yet emerged as a relevant factor in choosing electricity products. Purchase became an action adopted in the private context, with little presence in local social relationships. This may explain why respondents in the control group, who were not exposed to further information about green electricity, felt that buying green electricity would not be an opportunity for them to conform to expectations of their reference groups. However, as evidenced by the finding that SN becomes significant for respondents in the experimental groups, by activating social norms in a targeted population (through advertising, public information and debate, etc.), an effect of social interaction on intention and behaviour can actually be induced (Biel and Thogersen, 2007; Cialdini, 2003; Harland et al., 1999).

The same procedure has been used to analyse the purchase behaviour (binary variable). A logistic regression (Model 1b) in the basic TPB framework ends up in an accurate model ( $\chi^{2}$ stat $=424.4$ [df $=2$ ]; $p=0.000$ ) able to predict $19.1 \%$ of the purchase probability. This result is reasonable given that we evaluate actual behaviours rather than stated behaviours, which are more common in the literature (e.g. Menges et al., 2005; Ozcaglar-Toulouse et al., 2006). Behavioural intention is a strong predictor for behaviour $(B=0.52$; $\mathrm{p}<0.001$ ): $73.9 \%$ of the 51 new subscriptions we observed were from customers with a favorable intention to buy. In accordance with TPB literature, Perceived Behavioural Control has a direct effect on behaviour $(B=0.25 ; p<0.001)$, in addition to its indirect effect through its influence on intention (Model 1a).

In a more exploratory approach (Fig. 2), Model 2a summarizes the results of a simultaneous linear regression of intention outside of the basic TPB framework, in which we introduce all 24 variables that could have a potential effect on the purchase decision: basic TPB variables and extensions, socio-demographic variables, etc. (see Appendix 1). In order to obtain a more precise analysis we consider the different components of the TPB variables separately instead of their aggregate form (injunctive and descriptive norms for SN; perceived simplicity and control perception for PBC; see Ajzen, 2002a; Rhodes and Courneya, 2003; Trafimow et al., 2002). A stepwise (and backward) selection method (threshold 0.1 ) provides an accurate model that explains more variance than Model $1 \mathrm{a}\left(\Delta \mathrm{R}^{2}=+11.8\right.$ percentage points). Among the 
Model 2 (Extended TPB plus Economic Variables)

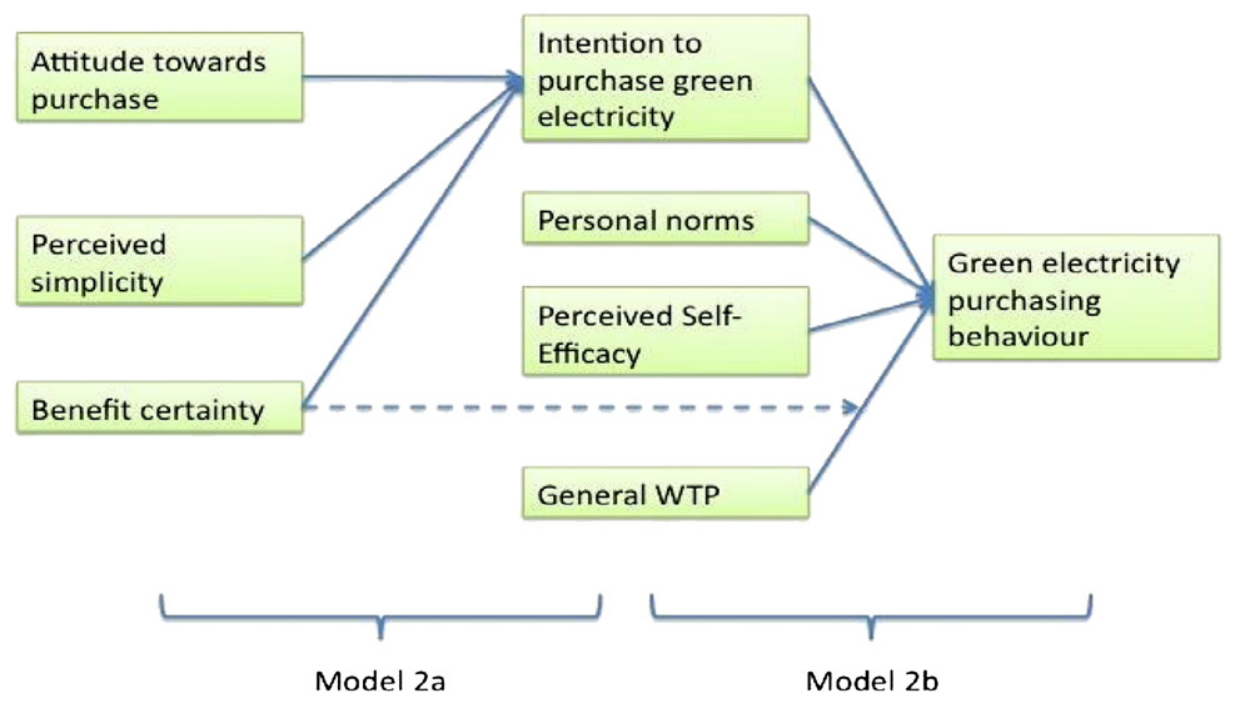

Fig. 2. Extended model of green electricity purchasing behaviour.

three significant variables remaining, two overlap with the basic TPB model: the attitude toward purchase $\left(A_{B}\right)(\beta=0.21 ; p<0.01)$ and the perceived simplicity $(\beta=0.14 ; p<0.05)$. The benefit certainty, an economic variable apart from TPB is more important $(\beta=0.45$; $\mathrm{p}<0.001)$ and its partial contribution is quite high $(+11.2 \%)$. All other things being equal, intention to purchase increases when the customer clearly perceives benefits of purchase. The causal influence of this variable on action is strong and robust, through its influence on intention.

Model 2b summarizes the results of a logistic regression of purchasing behaviour outside of the TPB framework, integrating all
24 variables as above. A forward selection (level 0.1) ends with a valid logistic model $\left(\chi^{2}\right.$ stat $\left.=397.9[d f=4] ; p<0.001\right)$ predicting action more accurately than the basic TPB model $(1 \mathrm{~b})\left(\chi^{2}\right.$ stat [change in the $-2 \log ]=17.75 ; \mathrm{p}<0.001)$. Results confirm the efficacy of TPB for predicting green electricity purchases: purchase intention is a significant factor which remains meaningful despite the integration of 24 variables, and perceived simplicity (one of the two components of PBC) is highly significant until general WTP is introduced in the model. Two other important factors complement the basic TPB model's prediction of behaviour: the level of personal norms $(B=0.32 ; \mathrm{p}<0.05)$ and perceived self-efficacy $(B=0.11 ; \mathrm{p}<0.001)$.

Table 4

Difference of mean between groups for predictors of intention (ANOVA and post-hoc tests).

\begin{tabular}{|c|c|c|c|c|c|}
\hline Variable tested & Groups (I) & Mean (SD) & $\neq$ of mean $^{\mathrm{a}}(\mathrm{I})-(\mathrm{J})$ & st. error & ANOVA $^{\mathrm{b}} \mathrm{F}(\mathrm{df}) /$ sig \\
\hline \multirow[t]{6}{*}{ Attitude toward green electricity purchase $\left(A_{B}\right)$} & $\mathrm{G}_{\mathrm{AB} 1}$ & $4.55(0.97)$ & $0.62^{\dagger}$ & $(0.08)$ & \multirow[t]{6}{*}{$4.90(6 ; 1001) / \mathrm{p}=0.00 \dagger$} \\
\hline & $\mathrm{G}_{\mathrm{AB} 2}$ & $4.32(1.03)$ & $0.39^{* *}$ & $(0.08)$ & \\
\hline & $\mathrm{G}_{\mathrm{SN}}$ & $4.35(1.07)$ & $0.35^{* *}$ & $(0.08)$ & \\
\hline & $\mathrm{G}_{\mathrm{PBC}}$ & $4.25(1.03)$ & 0.22 & $(0.08)$ & \\
\hline & $\mathrm{G}_{\text {Mixed }}$ & $4.15(1.08)$ & 0.12 & $(0.08)$ & \\
\hline & Control $(\mathrm{J})$ & $4.03(1.11)$ & - & $(0.09)$ & \\
\hline \multirow[t]{6}{*}{ Perceived personal Benefit } & $\mathrm{G}_{\mathrm{AB} 1}$ & $3.83(1.45)$ & $0.66 \dagger$ & $(0.11)$ & \multirow[t]{6}{*}{$3.56(6 ; 995) / \mathrm{p}=0.00 \dagger$} \\
\hline & $\mathrm{G}_{\mathrm{AB} 2}$ & $3.67(1.56)$ & $0.50^{* * *}$ & $(0.12)$ & \\
\hline & $\mathrm{G}_{\mathrm{SN}}$ & $3.48(1.58)$ & 0.31 & $(0.12)$ & \\
\hline & $\mathrm{G}_{\mathrm{PBC}}$ & $3.46(1.55)$ & 0.30 & $(0.12)$ & \\
\hline & $\mathrm{G}_{\text {Mixed }}$ & $3.60(1.54)$ & $0.44^{* * *}$ & $(0.12)$ & \\
\hline & Control $(\mathrm{J})$ & $3.16(1.54)$ & - & $(0.12)$ & \\
\hline \multirow[t]{6}{*}{ Perceived simplicity } & $\mathrm{G}_{\mathrm{AB} 1}$ & $3.86(1.70)$ & -0.08 & $(0.13)$ & \multirow[t]{6}{*}{$0.72(6 ; 984) / p=0.61$} \\
\hline & $\mathrm{G}_{\mathrm{AB} 2}$ & $3.92(1.69)$ & -0.02 & $(0.13)$ & \\
\hline & $\mathrm{G}_{\mathrm{SN}}$ & $3.97(1.74)$ & 0.03 & $(0.13)$ & \\
\hline & $\mathrm{G}_{\mathrm{PBC}}$ & $4.17(1.69)$ & 0.23 & $(0.13)$ & \\
\hline & $\mathrm{G}_{\text {Mixed }}$ & 4.08 (1.77) & 0.14 & $(0.14)$ & \\
\hline & Control (J) & $3.94(1.71)$ & - & $(0.13)$ & \\
\hline \multirow[t]{6}{*}{ Intention to purchase } & $\mathrm{G}_{\mathrm{AB} 1}$ & $3.02(1.74)$ & $0.60^{* * *}$ & $(0.14)$ & \multirow[t]{6}{*}{$2.33(5 ; 1001) / \mathrm{p}=0.04^{* *}$} \\
\hline & $\mathrm{G}_{\mathrm{AB} 2}$ & $2.88(1.84)$ & $0.46^{*}$ & $(0.14)$ & \\
\hline & $\mathrm{G}_{\mathrm{SN}}$ & $2.86(1.72)$ & $0.43^{*}$ & $(0.13)$ & \\
\hline & $\mathrm{G}_{\mathrm{PBC}}$ & $2.90(1.79)$ & $0.50^{* *}$ & $(0.14)$ & \\
\hline & $\mathrm{G}_{\text {Mixed }}$ & $2.90(1.83)$ & $0.47^{*}$ & $(0.14)$ & \\
\hline & Control $(\mathrm{J})$ & $2.42(1.71)$ & $0.60^{* * *}$ & $(0.13)$ & \\
\hline
\end{tabular}

$* \mathrm{p}<0.1 ; * * \mathrm{p}<0.05 ; * * * \mathrm{p}<0.01 ; \dagger \mathrm{p}<0.001$.

a Post-hoc tests: Dunett and Bonferroni (for homogeneity of variances).

b Levene's tests have confirmed the homogeneity of variance between groups for all variables. 
Table 5

Share of customers switching to green electricity within two months after the survey, by experimental group.

\begin{tabular}{|c|c|c|c|c|c|c|c|c|c|}
\hline & & \multicolumn{7}{|l|}{ Group } & \multirow[t]{2}{*}{ Tota } \\
\hline & & $\mathrm{G}_{\mathrm{AB} 1}$ & $\mathrm{G}_{\mathrm{AB} 2}$ & $\mathrm{G}_{\mathrm{SN}}$ & $\mathrm{G}_{\mathrm{PBC}}$ & $\mathrm{G}_{\text {Mixed }}$ & $\begin{array}{l}\text { Subtotal experimental } \\
\text { groups }\end{array}$ & Control group & \\
\hline Total & $\mathrm{N}$ & 164 & 163 & 177 & 165 & 168 & 837 & 170 & 1007 \\
\hline Of which positive attitude to green electricity & $\mathrm{N}$ & 123 & 120 & 124 & 118 & 129 & 614 & 125 & 739 \\
\hline No purchase & $\mathrm{N}$ & 108 & 107 & 113 & 109 & 113 & 550 & 120 & 670 \\
\hline Purchase & $\mathrm{N}$ & 15 & 13 & 11 & 9 & 16 & 64 & 5 & 69 \\
\hline $\begin{array}{l}\text { New Purchasers in \% of those with positive attitude } \\
\text { towards green electricity }\end{array}$ & $\%$ & $12.2 \%$ & $10.8 \%$ & $8.9 \%$ & $7.6 \%$ & $12.4 \%$ & $10.4 \%$ & $4.0 \%$ & $9.3 \%$ \\
\hline Signific. p (2-tailed) & & 0.014 & 0.036 & 0.115 & 0.191 & 0.010 & & $\mathrm{~N} / \mathrm{A}$ & $\mathrm{N} / \mathrm{A}$ \\
\hline
\end{tabular}

All else being equal, the purchase probability increases with a higher moral obligation to subscribe (resulting from the internalization of social norms into personal values) and when the customer thinks his individual contribution (and not only the collective action) may be an effective form of pro-environmental behaviour. These findings confirm the results of other studies related to green electricity (Clark et al., 2003; Kotchen and Moore, 2007; Peters and Feldman, 2001 ) and other behaviours (Ajzen and Fishbein, 2005; Kaiser et al., 2005; Parker et al., 1995; Manstead and Van Eekelen, 1998; Trafimow et al., 2002), indicating that these two constructs are indeed useful extensions of the basic TPB model. Finally, general WTP is the most important and significant variable (change in the $-2 \log =17.76$; $\mathrm{p}<0.001$ ). The more a customer accepts the general idea of paying more for green electricity, the higher his purchase probability $(\mathrm{B}=0.58 ; \mathrm{p}<0.001)$.

The discussion above shows that the TPB offers a useful model to understand the factors determining intention to buy and the actual purchasing behaviour for green electricity. We could also show that integrating a number of extensions to the TPB model as discussed in previous literature, but also economic variables such as benefit certainty and general WTP, increases the explanatory power of the model. We will see in section 4.3 below that apart from its important influence on intention, the perception of benefit also has an additional influence on behaviour by moderating the relationship between WTP and action. Before drilling deeper into this relationship, the following section 4.2 will investigate differences in behaviour between experimental groups and control group, and will confirm partly the causality between perceived benefit and purchasing behaviour, by showing that we changed the perception of benefit in the experimental groups, what has had an impact on intention.

\subsection{Differences Between Experimental Groups and Resulting Changes in Behaviour}

We showed that the perception of benefit is highly correlated with intention to purchase. But intention is an important determinant of the actual decision to purchase: perceiving a benefit from action is then a potential indirect determinant of purchasing green electricity. Did the treatment of our experimental groups increase the perceived benefit from purchasing green electricity? The results are shown in Table 4. An ANOVA (homogeneity of variance) confirms a difference of mean between at least 2 groups and the score's mean is significantly higher in $\mathrm{G}_{\mathrm{AB} 1}, \mathrm{G}_{\mathrm{AB} 2}$ and $\mathrm{G}_{\text {mixed }}$ than in the control group.

Average attitude toward green electricity purchase $\left(A_{B}\right)$ has also increased in those groups, but not the perceived simplicity of action. Finally, reinforcing these determinants of action has increased the intention to purchase in all groups, but above all in $G_{A B 1}$. But what about the actual purchasing behaviour?

A particularly interesting feature of our study is that we could actually observe behaviour of respondents in the four months after participating in the survey (Table 5). Of the 1007 respondents in the total sample who were not buying green electricity at the time of participating, 739 (73\%) had expressed a positive attitude towards green electricity (score 4-7 on a 7-point scale). Of those 739 potential green electricity customers, 69 (9.3\%) actually followed through on their intentions within the following four months, whereby most of these new subscriptions occurred between one and two months after the survey. While $10.4 \%(n=64)$ of respondents in the experimental groups switched to green electricity after participating in the survey, only $4.0 \%(n=5)$ of those in the control group did so. Applying a twotailed Fisher's exact test, we can further see that while the share of new customers is higher in all experimental groups than in the control group, this difference is only significant in three groups, namely the two groups that were exposed to information addressing their attitude toward behaviour ( $\mathrm{AB} 1$ and $\mathrm{AB} 2$ ) and the mixed group, while the difference to the control group is positive, but not significant for the groups that were treated on social norms (SN) and perceived behavioural control (PBC).

We can conclude that three types of information most effectively influenced a move from intention to action: (1) information on the social benefits of green electricity (targeting the pure altruist motivation $/ G_{A B 1}$ ); (2) information on the opportunity to privately benefit from green electricity development (targeting the egoistic motivation $/ \mathrm{G}_{\mathrm{AB} 2}$ ); and (3) providing a mix of information addressing all three TPB belief categories (targeting simultaneously the different altruist motivations $/ \mathrm{G}_{\text {mixed }}$ ). Overall, processing some standardized information targeted at these belief categories reliably increases the probability of green electricity purchase compared with a situation where no information is provided.

An important observation is that the groups where we could significantly increase action are precisely the ones where we improved the level of perceived benefit (see Table 4). By providing information targeting beliefs toward green electricity purchase, we could reinforce salient beliefs and clarify preferences; this has strengthened the perceived benefit of purchasing, which in turn has experimentally increased action. ${ }^{11}$ The experimental treatment has been particularly effective to encourage those individuals with a weakly positive attitude towards green electricity to move from intention to action. Indeed, we observe that, in the control group, all the 5 new subscribers had stated a highly positive attitude towards green electricity ( 7 out of 7 on a Likert-Scale); meanwhile only 10 to $30 \%$ of the new subscribers had such a very favorable attitude in the experimental groups, while the large majority stated only a moderately positive attitude towards green electricity (scores 5 to 6 out of 7), or in some cases even a neutral attitude towards green electricity. This result supports the idea that when consumers consolidate their beliefs about purchasing green electricity, providing

\footnotetext{
${ }^{11}$ We should note (Table 4) that the other significant antecedents of intention have not been increased precisely in these 3 groups, and not so homogeneously (a similar difference of mean between groups induce a similar increase in behaviour probability). This is a signal of the causal relation we are stressing between perception of benefit and change in behaviour.
} 
Table 6

Predictive power of general WTP on purchase behaviour, by level of perceived benefit certainty ${ }^{* *}$.

\begin{tabular}{|c|c|c|c|c|}
\hline \multirow{2}{*}{$\frac{\text { Level of perceived benefit } \rightarrow}{\text { Group (sample) } \rightarrow}$} & \multicolumn{2}{|l|}{ Low } & \multicolumn{2}{|l|}{ High } \\
\hline & Control & Treated & Control & Treated \\
\hline General WTP & $2.17(1.08) / \mathrm{p}=0.04$ & $1.11(0.41) / \mathrm{p}=0.007$ & $0.68(0.20) / \mathrm{p}=0.001$ & $0.48(0.68) / \mathrm{p}=0.48$ \\
\hline Constant & $-14.35(6.15) / \mathrm{p}=0.02$ & $-9.18(2.28) / \mathrm{p}=0.00$ & $-5.11(1.13) / \mathrm{p}=0.00$ & $-5.29(4.13) / \mathrm{p}=0.20$ \\
\hline Pseudo $\mathrm{R}^{2}$ & 0.48 & 0.25 & 0.09 & 0.05 \\
\hline$\%$ correct predictions & $97.8 \%$ & $98.8 \%$ & $92.9 \%$ & $80.6 \%$ \\
\hline$-2 \log \left(\operatorname{LR} \chi^{2}(1)\right)$ & $10.4\left(8.8^{* * *}\right)$ & $33.0\left(10.3^{\dagger}\right)$ & $13.8(0.6)$ & $213.8\left(14.5^{\dagger}\right)$ \\
\hline $\mathrm{N}$ & 91 & 334 & 28 & 232 \\
\hline
\end{tabular}

** $\mathrm{p}<0.05 ;{ }^{* * *} \mathrm{p}<0.01 ; \dagger \mathrm{p}<0.001$.

calibrated information can effectively encourage light green consumers to walk the talk.

\subsection{Perception of Benefit Moderates the Role of Price in the Purchasing Decision}

In the extended model presented above (Fig. 2), we could see that general willingness-to-pay for green electricity (WTP) is a powerful predictor for the actual purchasing decision, along with intention to buy green electricity. Perceived benefit, in turn, is an important antecedent of intention. In the following section, we will investigate whether perceived benefit also has a moderating influence on the relationship between WTP, or price, and behaviour.

Based on a survey in the US, Wiser (2007) suggests that the most common reason for refusing to support green electricity is that benefits are not great enough to warrant paying a premium. Our survey underlines that general WTP explains customer behaviour especially when respondents perceive a low personal benefit of green electricity subscription. Table 6 presents the results of a binary logistic regression predicting purchase behaviour as a function of the general WTP for two levels of perception of individual benefit on a 7-point Likert scale: low (scores 1-3) or high benefit (scores 5-7). We ran these regressions in two different samples: the control group and all the treated groups together. ${ }^{12}$

We can see that in the control group, with no treatment on beliefs towards green electricity purchase, the general acceptance of paying a premium is a powerful predictor of actual purchase probability independent of the level of perceived benefit, as discussed in our correlation analysis (Model $2 \mathrm{~b}$ in Table 3 ). However, for respondents who processed targeted information (treated groups), this result is observed only if their perceived benefit is low. In the case where respondents perceive a positive benefit from purchasing, their action is no longer related to their self-reported general WTP. We find the same result when splitting the sample according to the level of benefit certainty $^{13}$ : individuals uncertain about their benefit are sensitive to the barrier of paying more, but after processing information the ones certain of their benefit act independently of the existence of a price premium. We can conclude that perceived benefit has not just a strong indirect impact on action through intention, but - especially when benefit certainty is enhanced through specific information targeting salient beliefs - this variable also moderates the impact of the most important predictor of behaviour, which is general WTP.

Fig. 3 conceptualizes the implications of this finding in graphical form. Simply speaking, the typical price-response curve that predicts demand for a good should diminish as price increases, ${ }^{14}$ appears to be

\footnotetext{
12 Regressions were conducted on all treated groups together because of the small numbers of new subscriptions in certain subsamples.

13 See Appendix 1 for a detailed description of the variable personal benefit certainty.

${ }^{14}$ We would like to point out that this figure generalizes from our specific empirical results in that our variable general WTP was not a continuous variable, but we only asked on a scale whether or not paying a premium would be acceptable.
}

only valid for the surveyed green electricity customers if perceived benefit is low. If the marketer succeeds in establishing a clear and credible benefit, the existence of a price premium is much less of a barrier for consumers to move from intention to action.

Another way to look at this is that it confirms an old salesman's wisdom: ${ }^{15}$ Never talk to a customer about price until you have fully explained the value of your product, because deciding on price is the mental last resort of a customer who does not see other benefits to base his decision on.

\section{Limitations and Further Research}

While we believe our large-scale survey has combined a number of innovative methodological elements from psychology and economic analysis of consumer behaviour related to green electricity, it is also subject to a number of limitations that can serve as starting points for further research.

First of all, by soliciting participation in our online survey through a paper bill insert, we confronted potential respondents with a media discontinuity, resulting in a participation rate that was low compared to purely paper-based surveys. On the other hand, conducting the survey online allowed us to use interactive elements like graphics and flash animations in the information treatment part of the questionnaire, so going the paper route would have resulted in a loss of richness of the experimental design. We compensated the relatively low response rate by a broad distribution of invitations to participate (31,000 bill inserts) to get a sufficient sample size. Further researchers who do not have the means to widely distribute paper invitations may want to explore the option of soliciting participation online through pop-up windows on utility websites or price comparison sites, or through online discussion fora related to electricity products. One thing to consider though is whether recruiting participants online will maintain the relatively good representativeness of the sample that we enjoyed. The prospects of doing purely web-based surveys are probably improving over time, especially in countries with high internet penetration rates (such as Switzerland with about 95\%) and in regions where utilities have succeeded in switching a significant share of their customers to e-billing solutions.

Another limitation refers to the differential effect of the information provided to the treatment groups. Our analysis of differences in chapter 4.2 showed that the differences were statistically significant only for some of the groups. One way to address this in further research would be to work with even larger samples of consumers, so that the number of new subscribers resulting from a field experiment would be sufficiently large in each subsample. This would then also allow to further investigate what actually is more important from a practical impact perspective: carefully targeted information that is

\footnotetext{
15 http://salesandmarketingtips.today.com/2009/04/01/never-talk-price-and-otherimportant-cliches/.
} 


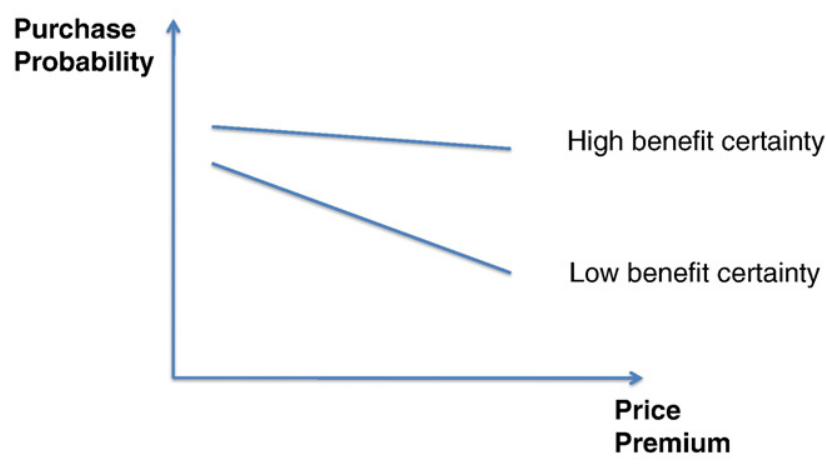

Fig. 3. The moderating effect of benefit certainty on price sensitivity.

tailored to the factors in the TPB model, or simply treating consumers with any kind of relevant information in order to overcome their inertia.

Further research should also extend our analysis to other geographies to assess the validity of the different belief categories across different cultural contexts. In particular, previous research has indicated that electricity customers in Switzerland are significantly less price sensitive than their peers in countries like Germany, the UK or the Netherlands (Wüstenhagen, 2000), and at the time of the survey, Switzerland was also different from other countries in that meaningful policy incentives for renewable energy generation (e.g. feed-in tariffs) were essentially nonexistent, making green electricity purchasing the only way to support renewables. It would be interesting to see whether these factors influence the validity of a TPB model and extensions when conducting similar experimental studies in other countries.

Finally, our findings indicate that WTP surveys have some inherent limitations in predicting how customers will actually react to prices offered at stated premiums. Further research should therefore explore alternative approaches to find valid measures for true price sensitivities. This may involve discrete choice experiments, where consumers have to simultaneously trade off price against other product attributes (Burkhalter et al., 2009); analysis of test markets; or the use of click stream data from actual electricity product configuration websites of power marketers (e.g. using Google Analytics).

\section{Conclusions}

Many consumers have positive attitudes towards renewable energy, but relatively few translate those into specific action in terms of purchasing green electricity. Our research sheds new light on the gap between intention and behaviour, demonstrating specific ways to help consumers increase the consistency between what they say and what they do. Based on our analysis, we can answer the three research questions outlined above as follows:

1. What is the influence of perceived benefit on explaining consumer decisions to purchase green electricity, and what are the key components of this benefit? In line with the Theory of Planned Behaviour (TPB), we show that behavioural, normative and control beliefs all influence the decision to purchase green electricity. Information directed towards each of these three factors can help to increase perceived benefit, and consequently actual purchasing behaviour.

2. What is the relative role of price in explaining barriers to purchasing green electricity? Our results show that general WTP is a good predictor of purchasing behaviour. Also, the importance of price decreases when benefits are clearly perceived, and when social norms are successfully activated - an effect that has received relatively little attention in marketing surveys on green electricity. This points to the need to better understand the formation of consumer preferences for green electricity, as well as the link between preferences and action.

3. How can green electricity marketers or policy makers increase the perceived benefits of purchasing green electricity? As evidenced by our survey, three types of information most effectively influenced a move from intention to action: information on the social benefits of green electricity; information on the opportunity to privately benefit from green electricity; and providing a mix of information addressing all three TPB belief categories. Processing some standardized information targeted at these belief categories has increased the probability of green electricity purchase compared with a situation where no information is provided. With some adaptation to specific national and local circumstances, using the kind of information provided in our survey will prove helpful to target the large segment of "light green" consumers, i.e. those who have positive intentions and/or attitudes, but have not yet followed through on actually purchasing green electricity. When it comes to pricing, our findings about the nuanced role of pricing should encourage marketers to design more creative pricing strategies than simple rules-of-thumb like "not more than $10 \%$ more per kWh" widely used in the electric utility industry.

For policy makers, our results indicate that consumer willingness to contribute to the achievement of renewable energy policies may be more widespread than disappointingly small market shares for green electricity might suggest. Indeed we could increase the share of subscribers who had been exposed to green electricity offerings for five years but have not taken the opportunity to buy - in other words: we succeeded in motivating hesitant "light greens" to walk the talk. Hence green power marketing may prove to be complementary to, although not a substitute for, other renewable energy policies (Litvine, 2009; Menges, 2003; Wüstenhagen and Bilharz, 2006). At the same time, our findings provide a vivid illustration of the multitude of factors that need to come together in order to make real behavioural changes. Policies such as green defaults (Pichert and Katsikopoulos, 2008, Karsten and Reisch, 2008) that make such behavioural changes easy for customers may prove very beneficial. The results presented here also provide an empirical justification for such policies in that $73 \%$ of consumers in our study reported positive attitudes to renewable energy, so current defaults in the electricity market seem to be far from maximizing customer value (Burkhalter et al., 2009). The different motivations constituting the potential benefit of buying green electricity are complex, and adequately addressing this complex set of motivations will strengthen the link from attitude to behaviour. We offered a framework and empirically demonstrated that a favorable attitude toward green electricity has a positive influence on the customer's purchase behaviour, even when this attitude is weak, neutral or latent.

Finally, as for further research, our study highlights the predictive power of models that take both psychological and economic variables into account, such as the TPB approach used in our research. More sophisticated market research integrating economic tools with the rich wisdom of other social science disciplines, such as social psychology, seems to be essential in order to get a more sophisticated understanding of what drives consumer behaviour related to green electricity. And last but not least, our study provides an indication for action research. Designed as a behavioural intervention study, the present survey provides an objective measure of purchasing behaviour and causal conclusions which can provide specific recommendations for green electricity marketers. Good research and practical relevance are far from being mutually exclusive, and a survey based on a solid theoretical foundation can be an effective way of supporting the accelerated market diffusion of renewable energy. 


\section{Acknowledgements}

The research presented in this paper was financially supported by Sankt Galler Stadtwerke. The feedback and support provided by Peter Graf and Peter Huesmann throughout the project is highly appreciated, as is Jacques Percebois' guidance and constructive support. We thank Benoit Mulkay for his assistance in data processing and Andreas Burkhalter for research assistance, as well as David Trafimow, Nadine Chaurand, Icek Ajzen, Lori Bird, Robert Cialdini and Norbert Schwarz for valuable exchanges. We thank two anonymous reviewers for valuable advice to improve the paper. Any remaining shortcomings are the sole responsibility of the authors.

\section{Appendix 1. List of variables}

\begin{tabular}{|c|c|c|c|c|c|c|c|c|}
\hline \multirow[t]{2}{*}{ Category } & \multirow[t]{2}{*}{ Variables $^{\mathrm{a}}$} & \multirow{2}{*}{$\begin{array}{l}\text { References } \\
\text { (concept and wording) }\end{array}$} & \multirow[t]{2}{*}{ Question in the survey ${ }^{c}$} & \multicolumn{5}{|c|}{ Descriptive statistics (\%) ${ }^{\mathrm{d}}$} \\
\hline & & & & Negative & Medium & Positive & Mean & $(\mathrm{SD})$ \\
\hline \multirow[t]{9}{*}{$\begin{array}{l}\text { TPB variables with three } \\
\text { extensions }\end{array}$} & $\begin{array}{l}\text { Attitude towards } \\
\text { purchase }\left(A_{B}\right)\end{array}$ & Ajzen, 1988, 1991, 2002a & $\begin{array}{l}\text { For me switching to green electricity in } \\
\text { the coming months is... [good/bad, } \\
\text { harmful/beneficial, worthless/valuable } \\
\text { and crucial/secondary] }\end{array}$ & 22.3 & 34.4 & 43.3 & 2.21 & $(0.78)$ \\
\hline & $\begin{array}{l}\text { Descriptive norms } \\
(\mathrm{SN})\end{array}$ & $\begin{array}{l}\text { Ajzen, 2002a; Heath and Gifford, } \\
\text { 2002; Rhodes and Courneya, } 2003\end{array}$ & $\begin{array}{l}\text { For me the effort other citizens are } \\
\text { ready to make to switch to green } \\
\text { electricity is [very weak/very high] }\end{array}$ & 55.3 & 36.4 & 8.4 & 1.53 & $(0.65)$ \\
\hline & $\begin{array}{l}\text { Injunctive norms } \\
(\mathrm{SN})\end{array}$ & & $\begin{array}{l}\text { Most people who are important to me } \\
\text { [approve/disapprove] of my switching } \\
\text { to green electricity in the coming } \\
\text { months }\end{array}$ & 4.9 & 29.6 & 65.5 & 2.61 & $(0.58)$ \\
\hline & $\begin{array}{l}\text { Perception of control } \\
(\mathrm{PBC})\end{array}$ & $\begin{array}{l}\text { Ajzen, 2002a;2002b; Armitage \& } \\
\text { Conner, 1999; Manstead and Van } \\
\text { Eekelen, 1998; Pieters et al., 1998; } \\
\text { Rhodes and Courneya, 2003; } \\
\text { Trafimow et al., } 2002\end{array}$ & $\begin{array}{l}\text { Do you think you have enough } \\
\text { knowledge and information to take a } \\
\text { beneficial decision switching to green } \\
\text { electricity in the coming months? [not } \\
\text { at all/entirely] }\end{array}$ & 25.3 & 11.0 & 63.7 & 2.38 & $(0.86)$ \\
\hline & $\begin{array}{l}\text { Perceived simplicity } \\
(\mathrm{PBC})\end{array}$ & & $\begin{array}{l}\text { For me to switch to green electricity in } \\
\text { the coming months would be } \\
\text { [extremely difficult/extremely easy] }\end{array}$ & 34.3 & 28.9 & 36.8 & 2.02 & $(0.84)$ \\
\hline & $\begin{array}{l}\text { Perceived Self- } \\
\text { Efficacy (PSE) }\end{array}$ & & $\begin{array}{l}\text { By switching to green electricity in the } \\
\text { coming months I think my } \\
\text { contribution can play a role in the } \\
\text { development of green electricity in my } \\
\text { country [not at all/entirely] }\end{array}$ & 54.5 & 16.4 & 29.1 & 1.75 & $(0.88)$ \\
\hline & $\begin{array}{l}\text { Perceived Response- } \\
\text { Efficacy (PRE) }\end{array}$ & $\begin{array}{l}\text { Ajzen, 2002b; Bandura, 1997; } \\
\text { Harland et al., 1999; Heath and } \\
\text { Gifford, 2002; Kaiser, 2006; Kaiser } \\
\text { et al., 1999; Manstead, } 2000\end{array}$ & $\begin{array}{l}\text { By switching to green electricity in the } \\
\text { coming months I will provide a } \\
\text { significant effort, but outcomes of my } \\
\text { purchase will be up to my expectations } \\
\text { [not at all/entirely] }\end{array}$ & 24.6 & 26.6 & 48.7 & 2.24 & $(0.82)$ \\
\hline & Personal norms & & $\begin{array}{l}\text { Would you be more in line with } \\
\text { yourself by switching to green } \\
\text { electricity in the coming months? [not } \\
\text { alt all/entirely] }\end{array}$ & 15.3 & 29.0 & 55.7 & 2.40 & $(0.74)$ \\
\hline & Expected guilt & & $\begin{array}{l}\text { Would you feel guilty if you don't } \\
\text { switch to green electricity in the } \\
\text { coming months? [not at all/entirely] }\end{array}$ & 29.0 & 27.5 & 33.5 & 1.94 & $(0.85)$ \\
\hline \multirow[t]{4}{*}{$\begin{array}{l}\text { Economic } \\
\text { variables }\end{array}$} & $\begin{array}{l}\text { Personal benefit } \\
\text { certainty }\end{array}$ & & $\begin{array}{l}\text { My interest or personal benefit in } \\
\text { switching to green electricity in the } \\
\text { coming months is [very weak/very strong] }\end{array}$ & 42.7 & 31.3 & 26.1 & 1.83 & $(0.81)$ \\
\hline & & & $\begin{array}{l}\text { This personal benefit I would obtain by } \\
\text { switching to green electricity in the } \\
\text { forthcoming months is [very } \\
\text { uncertain/very certain] }\end{array}$ & 44.1 & 28.3 & 27.5 & 1.83 & $(0.83)$ \\
\hline & General WTP & Farhar, 1999; Wiser, 2007 & $\begin{array}{l}\text { Is it conceivable for you to pay an extra } \\
\text { amount to switch to green electricity in } \\
\text { the coming months? [Not at all/entirely] }\end{array}$ & 35.6 & 15.5 & 49.0 & 2.13 & $(0.91)$ \\
\hline & WTP $10 \%$ premium & & $\begin{array}{l}\text { An extra amount of about } 10 \% \text { for each } \\
\text { kWh of green electricity is [very low/ } \\
\text { very high] }\end{array}$ & 53.1 & 15.7 & 31.2 & 1.78 & $(0.89)$ \\
\hline \multirow[t]{3}{*}{$\begin{array}{l}\text { Environmental profile } \\
\text { (psychological and } \\
\text { strategic) }^{\mathrm{b}}\end{array}$} & $\begin{array}{l}\text { Sensitivity to } \\
\text { interaction (degree } \\
\text { of descriptive norms) }\end{array}$ & $\begin{array}{l}\text { Questions concerning everyday } \\
\text { environmental behaviour }{ }^{\mathrm{b}}\end{array}$ & $\begin{array}{l}\text { To which extent do you take into account } \\
\text { what others do as a factor to undertake an } \\
\text { environmental action? }\end{array}$ & 66.9 & 19.1 & 14.1 & 1.47 & $(0.73)$ \\
\hline & $\begin{array}{l}\text { Efficiency of an } \\
\text { individual action }\end{array}$ & & $\begin{array}{l}\text { A single individual's environmental } \\
\text { action is useless if others refuse to } \\
\text { make efforts too }\end{array}$ & 48.3 & 4.5 & 47.3 & 1.99 & $(0.98)$ \\
\hline & Perceived Self Efficacy & & $\begin{array}{l}\text { By undertaking an environmental action, } \\
\text { do you think your contribution has a } \\
\text { positive influence on the environment } \\
\text { and "can make the difference"? }\end{array}$ & 20.4 & 18.3 & 61.3 & 2.41 & $(0.81)$ \\
\hline
\end{tabular}


Appendix 1 (continued)

\begin{tabular}{|c|c|c|c|c|c|c|c|c|}
\hline \multirow[t]{2}{*}{ Category } & \multirow[t]{2}{*}{ Variables $^{\mathrm{a}}$} & \multirow{2}{*}{$\begin{array}{l}\text { References } \\
\text { (concept and wording) }\end{array}$} & \multirow[t]{2}{*}{ Question in the survey ${ }^{\mathrm{c}}$} & \multicolumn{5}{|c|}{ Descriptive statistics (\%) } \\
\hline & & & & Negative & Medium & Positive & Mean & $(\mathrm{SD})$ \\
\hline & $\begin{array}{l}\text { Perceived Response- } \\
\text { Efficacy }\end{array}$ & & $\begin{array}{l}\text { Do you feel that your contribution will } \\
\text { produce outcomes complying with my } \\
\text { expectations? }\end{array}$ & 36.4 & 24.5 & 39.1 & 2.03 & $(0.87)$ \\
\hline & Intrinsic motivation & & $\begin{array}{l}\text { Some individuals report that } \\
\text { undertaking an action is more } \\
\text { satisfying than the overall results of } \\
\text { this action. Is the action per se more/ } \\
\text { less important than the outcome of this } \\
\text { action? }\end{array}$ & 32.1 & 14.8 & 53.1 & 2.21 & $(0.90)$ \\
\hline & Passive free riding & & $\begin{array}{l}\text { I'm less disposed to undertake an } \\
\text { environmental action if I know that } \\
\text { others do not contribute to it }\end{array}$ & 59.1 & 14.6 & 26.3 & 1.67 & $(0.86)$ \\
\hline & $\begin{array}{l}\text { Fear of others' free } \\
\text { riding }\end{array}$ & & $\begin{array}{l}\text { The government should require } \\
\text { everyone to help pay for } \\
\text { environmental improvements as it is } \\
\text { mutually beneficial }\end{array}$ & 34.2 & 8.5 & 57.3 & 2.23 & $(0.93)$ \\
\hline & $\begin{array}{l}\text { Attitude toward green } \\
\text { electricity }\end{array}$ & & $\begin{array}{l}\text { My global opinion of green electricity } \\
\text { is [totally unfavorable/totally } \\
\text { favorable] }\end{array}$ & 8.8 & 17.9 & 73.3 & 2.64 & $(0.64)$ \\
\hline & Environmental concern & & $\begin{array}{l}\text { Among the five following actions, } \\
\text { which ones you and your household do } \\
\text { regularly (score from } 0 \text { to } 5 \\
\text { transformed into a vector }[0,1] \text { ). }\end{array}$ & - & - & - & 0.73 & $(0.21)$ \\
\hline Socio-demographic & $\begin{array}{l}\text { Age, gender, income, } \\
\text { education/profession }\end{array}$ & & See Table 1 & - & - & - & - & \\
\hline
\end{tabular}

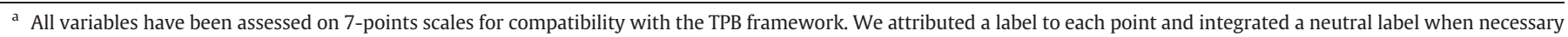
for understanding. The level of ecological behaviour is a list of 5 binary variables transformed into a float included between 0 and 1 .

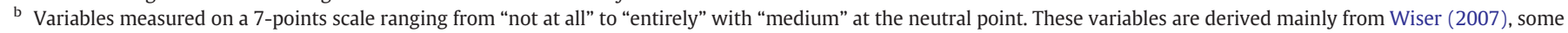
models of ecological action (Dietz et al., 1998; Kaiser et al., 1999; Pieters et al., 1998; Thogersen and Olander, 2003), but also Bearden et al. (1989).

c The original questionnaire was conducted in German, translation by the authors.

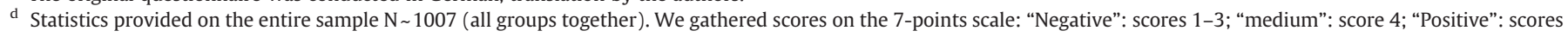
$5-7$.

\section{References}

Abrahamse, W., Steg, L., Vlek, C., Rothengatter, T., 2005. A review of intervention studies aimed at household energy conservation. Journal of Environmental Psychology 25, $273-291$.

Ajzen, I., 1988. Attitudes, Personality, and Behaviour. Dorsey Press, Chicago.

Ajzen, I., 1991. The theory of planned behaviour. Organizational Behavior and Human Decision Processes 50, 179-211.

Ajzen, I., 2002a. Perceived behavioral control, self-efficacy, locus of control, and the Theory of Planned Behavior. Journal of Applied Social Psychology 32, 1-20.

Ajzen, I., 2002b. Constructing a Theory of Planned Behavior Questionnaire: Conceptual and Methodological Considerations. www-unix.oit.umass.edu/ aizen2002.

Ajzen, I., 2002c. Behavioral Interventions Based on the Theory of Planned Behavior. www-unix.oit.umass.edu2002.

Ajzen, I., Fishbein, M., 2005. The Influence of Attitudes on Behaviour. In: Albarracín, D., Johnson, B., Zanna, M. (Eds.), The handbook of attitudes, Lawrence Erlbaum Associates Mahwah, NJ, pp. 173-221.

Andreoni, J., 1988. Privately provided public goods in a large economy: the limits of altruism. Journal of Public Economics 35, 57-73.

Andreoni, J., 1990. Impure altruism and donation to public goods: a theory of warmglow giving. The Economic Journal 100, 464-477.

Armitage, C., Conner, M., 1999. The theory of planned behaviour: assessment of predictive validity and perceived control. British Journal of Social Psychology 38, 35-54.

Arthur, W.B., 1989. Competing technologies, increasing returns, and lock-in by historical events. The Economic Journal 99, 116-131.

Bamberg, S., Möser, G., 2007. Twenty years after Hines, Hungerford, and Tomera: a new meta-analysis of psycho-social determinants of pro-environmental behaviour. Journal of Environmental Psychology 27, 14-25.

Bamberg, S., Schmidt, P., 1998. Changing travel-mode choice as rational choice. Rationality and Society 10 (2), 223-252.

Bandura, A., 1977. Self-efficacy: toward a unifying theory of behavioral change. Psychological Review 84, 191-215.

Bandura, A., 1997. Self-efficacy: the exercise of control. WH. Freeman \& Co., New York

Bang, H.K., Ellinger, A., Hadjimarcou, J., Traichal, P., 2000. Consumer concern, knowledge, belief and attitude toward renewable energy: an application of the reasoned action theory. Psychology and Marketing 17 (6), 449-468.

Bator, R., Cialdini, R., 2000. New ways to promote pro-environmental behavior: the application of persuasion theory to the development of effective pro-environmental public service announcements. Journal of Science 56 (3), 527-541.

Bearden, W., Netemeyer, R., Teel, T., 1989. Measurement of consumer susceptibility to interpersonal influence. Journal of Consumer Research 15, 473-481.
Bergstrom, T., Blume, L., Varian, H., 1986. On the private provision of public goods. Journal of Public Economics 29, 25-49.

Biel, A., Thogersen, J., 2007. Activation of social norms in social dilemmas: a review of the evidence and reflections on the implications for environmental behaviour. Journal of Economic Psychology 28 (1), 93-112.

Bird, L., Wüstenhagen, R., Aabakken, J., 2002. A review of international green power markets: recent experience, trends, and market drivers. Renewable \& Sustainable Energy Reviews 6 (6), 513-536.

Borchers, A., Duke, J., Parsons, G., 2007. Does willingness to pay for green energy differ by source? Energy Policy 35, 3327-3334.

Brekke, K.A., Kverndokk, S., Nyborg, K., 2003. An economic model of moral motivation. Journal of Public Economics 87, 1967-1983.

Bundesamt für Statistik [BFS], 2005. Eidgenössische Volkszählung 2000. Haushalte und Familien, Neuenburg.

Bundesamt für Statistik [BFS], 2007. Schweizerische Lohnstrukturerhebung 2006. Bundesamt für Statistik, Neuenburg.

Burkhalter, A., Känzig, J., Wüstenhagen, R., 2009. Kundenpräferenzen für leistungsrelevante Attribute von Stromprodukten. Zeitschrift für Energiewirtschaft 33 (2), 161-172.

Byrnes, B., Jones, C., Goodman, S., 1999. Contingent valuation and real economic commitments: evidence from electric utility green pricing. Journal of Environmental Planning and Management 42 (2), 149-166.

Cialdini, R., 2003. Crafting normative messages to protect the environment. Current Directions in Psychological Science 12, 105-109.

Clark, C., Kotchen, M., Moore, M., 2003. Internal and external influences on proenvironmental behaviour: participation in a green electricity program. Journal of Environmental Psychology 23, 237-246.

De Groot J., Steg L., 2010. Relationships between value orientations, self-determined motivational types and pro-environmental behavioural intentions. Journal of Environmental Psychology 30 (4), 368-378.

Dietz, T., Stern, P., Guagnano, G., 1998. Social structural and social psychological bases of environmental concern. Environment and Behavior 30 (4), 450-471.

Ek, K., Söderholm, P., 2008. Norms and economic motivation in the Swedish green electricity market. Ecological Economics 68, 169-182.

Eurobarometer, 2005. The attitudes of European citizens towards the environment. European Commission, Brussels. http://ec.europa.eu/public_opinion/archives/ebs/ ebs 217 sum en.pdf.

Farhar, B., 1999. Willingness to pay for electricity from renewable resources: a review of utility market researchNREL/TP-550-26148 http://www.nrel.gov/docs/fy99osti/ 26148.pdf1999.

Fishbein, M., 1995. Developing Effective Behavior Change Interventions: Some Lessons Learned from Behavioural Research. In: Backer, T., David, S., Saucy, G. (Eds.), Reviewing the behavioral science knowledge base on technology transfer. National Institute on Drug Abuse. 
Fishbein, M., Ajzen, I., 2005. Theory-based behavior change interventions: comments on Hobbis and Sutton. Journal of Health Psychology 10 (1), 27-31.

Fishbein, M., Ajzen, I., 2010. Predicting and Changing Behavior: The Reasoned Action Approach. Psychology Press (Taylor \& Francis), New York.

Goeree, J., Holt, C., Laury, S., 2002. Private costs and public benefits: unrevealing the effects of altruism and noisy behaviour. Journal of Public Economics 83, 255-276.

Hansla, A., Gamble, A., Juliusson, G., Gärling, T., 2007. Psychological determinants of attitude towards and willingness to pay for green electricity. Energy Policy 36 (2), 768-774.

Harland, P., Staats, H., Wilke, H., 1999. Explaining pro-environmental intention and behaviour by personal norms and the theory of planned behaviour. Journal of Applied Social Psychology 29 (12), 2505-2528.

Hausman, D., McPherson, M., 1996. Economic analysis and moral philosophy. Cambridge University Press, UK. 249 pp.

Heath, Y., Gifford, R., 2002. Extending the theory of planned behavior: predicting the use of public transportation. Journal of Applied Social Psychology 32 (10), 2154-2189.

Hopper, J., Nielsen, J., 1991. Recycling as altruistic behavior: normative and behavioral strategies to expand participation in a community recycling program. Environment and Behavior 23 (2), 195-220.

Jackson, T., 2005. Motivating sustainable consumption: a review of evidence on consumer behaviour and behavioural change. Sustainable Development Research Network.

Jacobsen, G., 2010. The Al Gore Effect: An Inconvenient Truth and Voluntary Carbon Offsets. www.econ.ucsb.edu/ jacobsen/JacobsenJMP.pdf2010.

Kaiser, F., 2006. A moral extension of the theory of planned behaviour: norms and anticipated feelings of regret in conservationism. Personality and Individual Differences 41 (1), 71-81.

Kaiser, F., Gutscher, H., 2003. The proposition of a general version of the theory of planned behavior: predicting ecological behaviour. Journal of Applied Social Psychology 33 (3), 586-603.

Kaiser, F., Ranney, M., Hartig, T., Bowler, P., 1999. Ecological behavior, environmental attitude, and feelings of responsibility for the environment. European Psychologist 4 (2), 59-74.

Kaiser, F., Hübner, G., Bogner, F., 2005. Contrasting the theory of planned behaviour with the value-belief-norm model in explaining conservation behaviour. Journal of Applied Social Psychology 35 (10), 2150-2170.

Kalafatis, S., Pollard, M., East, R., Tsogas, M., 1999. Green marketing and Ajzen's theory of planned behaviour: a cross-market examination. Journal of Consumer Marketing 16 (5), 441-460.

Karsten, J., Reisch, L., 2008. Sustainability policy and the law. German Policy Studies 4 (1) pp. \#\#\#.

Kotchen, M., 2006. Green markets and private provision of public goods. Journal of Political Economy 114 (4), 816-834.

Kotchen, M., Moore, M., 2007. Private provision of environmental public goods: household participation in green-electricity programs. Journal of Environmental Economics and Management 53 (1), 1-16.

Krosnick, J., 1999. Survey research. Annual Review of Psychology 50, 537-567.

Lindenberg, S., Steg, L., 2007. Normative, gain and hedonic goal frames guiding environmental behavior. Journal of Social Issues 63 (1), 117-137.

Litvine, D., 2008. Révélation des Préférences Individuelles et Incitation au Choix de l'Électricité Verte: Une Analyse de la Décision du Consommateur. PhD Thesis, University of Montpellier.

Litvine, D., 2009. A structural critic of French feed-in tariffs for small-scale hydraulic plants, WP-CREDEN.

Manstead, A., 2000. The Role of Moral Norm in the Attitude-Behavior Relation. In: Terry, D.J., Hogg, M. (Eds.), Attitudes, behavior, and social context: the role of norms and group membership. Lawrence Erlbaum Associates, NJ.

Manstead, A., Van Eekelen, S., 1998. Distinguishing between perceived behavioral control and self-efficacy in the domain of academic achievement intentions and behaviors. Journal of Applied Social Psychology 28 (15), 1375-1392.

Markard, J., Truffer, B., 2006. The promotional impacts of green power products on renewable energy source: direct and indirect eco-effects. Energy Policy 34, 306-321.

Menges, R., 2003. Supporting renewable energy on liberalised markets: green electricity between additionality and consumer sovereignty. Energy Policy 31, 583-596.

Menges, R., Schroeder, C., Traub, S., 2005. Altruism, warm glow and willingness-todonate for green electricity: an artefactual field experiment. Environmental \& Resource Economics 31, 431-458.

Nyborg, K., Howarth, R.B., Kjell, A.B., 2006. Green consumers and public policy: on socially contingent moral motivation. Resource and Energy Economics 28, 351-366.
Oreg, S., Katz-Gerro, T., 2006. Predicting proenvironmental behavior cross-nationally: values, the theory of planned behavior, and value-belief-norm theory. Environment and Behavior 38 (4), 462-483.

Ozcaglar-Toulouse, N., Shiu, E., Shaw, D., 2006. In search of fair trade: ethical consume decision making in France. International Journal of Consumer Studies 30 (5), 502-514.

Palfrey, T., Rosenthal, H., 1988. Private incentives in social dilemmas, the effect of incomplete information and altruism. Journal of Public Economics 35, 309-332.

Palmer, J., 2003. Consumer Choice and Carbon Consciousness for Electricity (4CE) Telephone Survey Analysis. ALTENER Project. European Commission.

Parker, D., Manstead, A., Stradling, S., 1995. Extending the theory of planned behaviour: the role of personal norm. The British Journal of Social Psychology 34, 127-137.

Peters, J., Feldman, S., 2001. I can do it! The role of self-efficacy in motivating changes in attitudes and behavior relating to energy efficiency and renewables. Proceedings of the 2001 International Energy Program Evaluation Conference, Salt Lake City, pp. 479-486.

Petty, R., Cacioppo, J., Schumann, D., 1983. Central and peripheral routes to advertising effectiveness: the moderating role of involvement. Journal of Consumer Research 10, 135-146.

Pichert, D., Katsikopoulos, K.V., 2008. Green defaults: information presentation and pro-environmental behaviour. Journal of Environmental Psychology 28, 63-73.

Pieters, R., Bijmolt, T., Raaij, F., Kruijk, M., 1998. Consumers' attributions of proenvironmental behavior, motivation, and ability to self and others. Journal of Public Policy and Marketing 7 (2), 215-225.

Poe, G., Clark, J., Rondeau, D., Schulze, W., 2002. Provision point mechanisms and field valdity tests of contingent valuation. Environmental \& Resource Economics 23 (1), 105-131.

Pratkanis, A., Greenwald, A., 1993. Consumer involvement, message attention, and the persistence of persuasive impact in a message-dense environment. Psychology and marketing 10 (4), 321-332.

Reiss, P., White, M., 2008. What changes energy consumption? Prices and public pressures. The Rand Journal of Economics 39 (3), 636-663.

REN21, 2010. Renewables 2010 Global Status Report. Paris, www.ren21.net.

Rhodes, R., Courneya, K., 2003. Investigating multiple components of attitude subjective norm, and perceived control: an examination of the theory of planned behaviour in the exercise domain. The British Journal of Social Psychology 42 129-146.

Roe, B., Teisl, M., Levy, A., Russell, M., 2001. US consumers' willingness to pay for green electricity. Energy Policy 29, 917-925.

Rose, S., Clark, J., Poe, G., Rondeau, D., Schulze, W., 2002. The private provision of public goods: test of a provision mechanism for funding green power programs. Ressources and Energy Economics 24, 131-155.

Schultz, P., 1998. Changing behavior with normative feedback interventions: a field experiment on curbside recycling. Basic and Applied Social Psychology 21 (1), 25-36.

Sparks, P., Shepherd, R., 1992. Self-identity and the theory of planned behaviour: assessing the role of identification with "green consumerism". Social Psychology Quarterly 55 (4), 388-399.

Steg L., de Groot J., Dreijerink L., Abrahamse W., Siero F., in press. General Antecedents of Personal Norms, Policy Acceptability, and Intentions: The Role of Values, Worldviews, and Environmental Concern. Society and National Resources.

Stern, P., 1999. Information, incentives, and proenvironmental consumer behavior Journal of Consumer Policy 22 (4), 461-478.

Sudman, S., Bradburn, N., Schwarz, N., 1996. Thinking about answers: the application of cognitive processes to survey methodology. Jossey-Bass, SF. 304 pp.

Tabachnick, B., Fidell, L., 2006. Using Multivariate Statistics, 5th ed. HarperCollins, NY

Thogersen, J., Olander, F., 2003. Spillover of environment-friendly consumer behaviour Journal of Environmental Psychology 23 (3), 225-236.

Trafimow, D., Sheeran, P., Conner, M., Finlay, K., 2002. Evidence that perceived behavioural control is a multidimensional construct: perceived control and perceived difficulty. The British Journal of Social Psychology 41, 101-121.

Verplanken, B., Wood, W., 2006. Interventions to break and create consumer habits. American Marketing Association 25 (1), 90-103.

Wiser, R., 2007. Using contingent valuation to explore willingness to pay for renewable energy: a comparison of collective and voluntary payment vehicles. Ecological Economics 62, 419-432.

Wüstenhagen, R., 2000. Ökostrom - von der Nische zum Massenmarkt. Zürich: vdf.

Wüstenhagen, R., Bilharz, M., 2006. Green energy market development in Germany: effective public policy and emerging customer demand. Energy Policy 34, 1681-1696. 